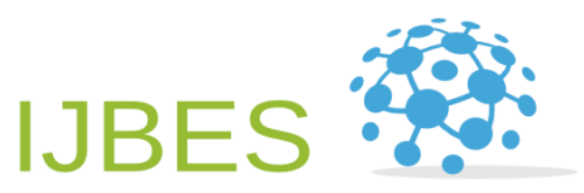

Business Ecosystem \& Strategy

\title{
Non-performing assets of banks and economicgrowth vinculum in the era of globalization: The Indian experience

\author{
Sovik Mukherjee
}

Assistant Professor, Department of Economics, Faculty of Commerce \& Management Studies, St. Xavier's University, Kolkata, India.

\section{ARTICLE INFO}

\section{Article history:}

Received 12 March 19

Received in rev. form 28 April 19

Accepted 10 June 19

Keywords:

Co-integration; FRDI Bill; Granger

Causality; NPA Ratio; Recession

JEL Classification:

$\mathrm{F} 1, \mathrm{O} 32$

\begin{abstract}
A B S T R A C T
The introduction of the New Economic Policy (NEP) in 1991 by the Government of India (GoI) made it very clear that the viability of commercial banks is conditioned on their ability to make profits. In a globalized world, the whims and fancies of business cycles govern the fate of banks and a recessionary phase hampers the bank's ability to pile on the profits thereby increasing their stock of non-performing assets. India, recently, is placed in a very bizarre situation, - some of the renowned banks are reporting huge losses but there is a very limited impact on stock markets. Strategically, the government, however, has taken corrective measures to arrest the growth of non-performing assets (NPAs) of banks. This paper builds upon a time series model capturing the position of NPAs of banks in India (excluding foreign banks operating in India). Empirically, there is a uni-directional causal relationship running from NPAs of banks to growth. Theoretically, what we can conclude is that imposing strict lending norms on banks actually manifests itself into a deeper recession, lowers growth and in turn aggravates the NPA problem further.
\end{abstract}

(c) 2019 by the authors. Licensee Bussecon International, Istanbul, Turkey. This article is an open access article distributed under the terms and conditions of the Creative Commons Attribution 4.0 International license (CC BY) (http://creativecommons.org/licenses/by/4.0/).

\section{Introduction}

The performance of the banking industry in India in FY 2009-10 was comparatively slow with some concerns arising with regards to the low quality of assets and the slow deposit growth in the backdrop of the US Subprime mortgage market crisis. The rise in the level of Gross NPAs as ratio to gross advances for scheduled commercial banks which started from 2.4 per cent in 2010, at present, stands at 9.85 per cent in 2017 (Word Bank Database, 2017). In the last five years, comparing the figures from the World Bank database, the paper points out a few notable insights in this regard. Among the developed countries, UK, USA, Japan and Germany had NPA ratios less than 2 per cent while among the emerging market economies, China, Argentina and Chile have been the top performers. Among BRICS, India's performance is the worst while that of China has been the best. Brazil and South Africa, which are also a part of BRICS consortium, had moderately high average ratios of 3.69 per cent and 2.83 per cent, respectively in these years.

The countries with higher NPA ratios apart from India Portugal, Greece, Italy, Ireland. A quote by Former RBI Governor, Dr. Raghuram Rajan in the year 2015 in the backdrop of a strategically managed clean-up drive by RBI where the commercial banks having severe debt obligation problems were identified actually sums up the graveness of the situation that since then India has been into and the way forward;

\footnotetext{
* Corresponding author. ORCID ID: 0000-0003-2001-9035

(C) 2019 by the authors. Hosting by Bussecon International Academy. Peer review under responsibility of Bussecon International Academy. http://dx.doi.org/10.36096/ijbes.v1i3.282 
We also supervise banks and go through their portfolios to see whether they have declared all the NPAs (nonperforming assets) they should. We examine divergences, and bank management is hauled up if there are divergences. Increasingly, we are turning towards taking action over such divergences. — said Dr. Rajan.

Digging deep into the macroeconomic causes (which is the focus area of this paper) of piling up of non-performing assets in the recent past in India, we glance through the different years since the beginning of the new millennium (see Figures 2 and 3 ). Besides, government intervention, it should be the prerogative of the concerned bank to put in place several internal strategies like — regular industrial visits, credit appraisal system, improper management information system and the repayment capacity of the borrower. Failure to manage such credit risks adds fuel to the fire. The first few years in the first decade of the new millennium, termed as the 'Golden Years' in the Indian economy (Nagaraj, 2013), is a witness to a massive boom phase with the investors becoming enthusiastic about investing in India. Their enthusiasm to invest drove up the interest rates. But with the onset of the global recession, their expectations changed drastically and they suffered huge losses (Ghosh et al., 2018). As the global recession began to spread its tentacles coupled with restrictions imposed on FDI \& FII and a drop in the credit ratings (Mukherjee and Karmakar, 2018), the apprehension levels of investors went up by a couple of notches. Thus, bringing about a rise in the growth rate of non-performing assets as a fraction of the total loans advanced. In such a case where business cycles are in full swing, predicting when a boom phase begins or when the economy downslides, i.e. a transition from one phase to the other becomes impossible. Here, one needs to be very careful in understanding the fact that whether every anti-recessionary policy works in the context of strategic management of nonperforming assets or not. In what follows, this paper notes the implications of "innovative boomerang" policies to regulate the nonperforming assets' position of banks in India, both theoretically and empirically.

The global economic downturn added fuel to fire and ever since then the NPAs of banks have persistently been on the rise. The situation became alarming in 2015 when it hit the 5.9 per cent mark. This prompted both the Government of India (GoI) and the Reserve Bank of India (RBI) to take stock of the situation and adopt a series of measures to arrest the growth of the banks' nonperforming assets. In a recent move, the government is planning to infuse new capital into the banks to maintain capital adequacy ratio as part of the GoI's Indra Dhanush programme. This infusement scheme have brought down the NPA ratios which otherwise would have been much worse. Apart from this, some of the public-sector banks have been put under the category that requires "Prompt Corrective Action (PCA)". All the banks in general and the public-sector banks in particular, have been put on high alert. Most alarmingly, the basic motivation for this research paper lies in the GoI's proposal to introduce the Financial Regulation and Deposit Insurance Bill (it had been tabled in the Parliament in August 2017 but not yet adopted). The problem stems from people perception regarding the inbuilt "bail-in clause" which says that to rescue a sick financial corporation (say, a bank) that is on the verge of becoming bankrupt, deposits held by the creditors and depositors will be used to bail out that financial institution as mentioned in Section 52 of this FRDI Bill. Unmistakably, this measure will destroy people's faith in banks. If people perceive that their deposited money is under risk, then their confidence will take a beating and go in for a toss. The moment people are reluctant to hold their money in the form of savings, the banking sector of the economy will not only collapse but along with it plot the collapse of the entire economy.

Based on the theoretical structure, this paper builds upon a time series model capturing the NPAs position of banks in India (excluding foreign banks operating in India). Also, the objective is to capture the long-term relationship between economic growth and nonperforming assets of banks alongside finding out the causality links, if any. Theoretically, what can be concluded is that the imposition of strict lending norms on banks actually intensifies the problem of recession which in turn aggravates the NPA problem further. Interestingly, there is a uni-directional causal liaison running from NPAs of banks to economic growth. This is a brief outline of what the paper talks about.

\section{Literature Review}

Starting with the rich literature on non-performing assets of banks, studies have happened across several dimensions which bring to forefront different perspectives. As a starting point, this paper discusses the liaison of NPAs with economic growth and then moves on to the different aspects of NPAs. There is a rich literature on the role played by financial and banking development in the process of economic growth [see, for instance, Stiglitz (1993); Beck and Levine (2004)]. In the new millennium, more precisely, in this era of globalization, Miwa and Ramseyer (2002) found no significant role of commercial banks in the economic growth process from historical evidence in Japan. Burzynska (2009) took the case of Chinese banking sector and identified a long-run equilibrium relationship between economic growth and financial development. In his study he found the direction of the causality between bank credit and economic growth most importantly depends not only on the type of the bank but also on the type of loan. In the Indian context, a study by Banerjee (2012) points to the variability in the direction of causality between economic growth and bank credit over time. The academic literature provides many evidence of studies in different dimensions to suggest a strong relationship between the non-performing loans of banks and many macroeconomic variables (Messai \& Jouini, 2013) like the real interest rate, the rate of GDP growth, the inflation rate, the real exchange rate, the unemployment rate, Money supply $\left(\mathrm{M}_{2}\right)$ etc.. However, in the Indian context such full blown models are a rare phenomenon.

In the recent past, with the onslaught of the financial crises (see Mukherjee \& Karmakar, 2018), many research papers are coming up which attribute non-performing assets of banks as one of the causes behind such debacles. Many of these studies give emphasis 
to the fact that the banks relied heavily on raising short-term funds from the capital markets for financing a substantial fraction of their loans due to growing NPAs (see, for instance, Adrian \& Shin, 2008; Gorton, 2010; Diamond \& Rajan, 2009). To quote, Kirkpatrick (2009), _ "the financial crisis can be to an important extent attributed to failures and weaknesses in corporate governance arrangements". Some academic studies also emphasize that poor bank governance led to excessive risk taking, causing them to make larger losses during the crisis periods (Bebchuk et al., 2010). Eurozone has beome the epicentre of financial crises on account of the sovereign debt problems for quite a few years now. Several studies have examined the determinants of problem loans in the context of Eurozone (Espinoza \& Prasad, 2010). However, Makri et al. (2014) presented the first empirical study highlighing the factors responsible for the fragile Eurozone banking system. Their study, brought in macroeconomic variables like public debt as percentage of GDP, unemployment and bank specific microeconomic variables like, return on assets and equity, capital adequacy ratio, etc. to investigate factors which determine NPAs at an aggregate level.

The motivation for the study lies in the fact that studies in the Indian context have looked at the different aspects of NPAs of banks but its liaison with growth remains unexplored. To begin with, considering the NPAs as an endogenous variable, our research adds to a growing literature, more precisely, we exclusively focus on India for the period 2005- 2017, using aggregate data of 42 public and private sector banks (excluding foreign banks). However, in a different context, there are a few noted empirical studies concerned with the problem of NPAs in the Indian banking system, include — Rajaraman et al. (1999); Rajaraman and Vasishtha (2000); Ranjan and Dhal (2003); Reddy (2004); Das and Ghosh (2007); Chaudhary (2012) among others. These studies have by and large looked into the productivity and operational efficiency of the banks in India. More recent among them includes — Cheema and Agarwal (2002), Ketkar et al. (2003), Saggar (2005). Studies have come to conclusions that public sector banks in comparison to private sector banks have registered more NPAs and more so in priority sector lending (Patidar \& Kataria, 2012; Gupta, 2012)

\section{Facts and issues related to NPAs in India: A recapitulation}

Post economic liberalization in 1991, the government decided to constitute various committees in order to review the functioning of the Indian banking system to come up with policy changes as required. Under the chairmanship of M. Narasimham in 1991 and later on, one in 1998, two committees were constituted to decide on the roadmap for the banking sector reforms in post-liberalization India. Several micro prudential measures including the introduction of "risk based capital standards" and "uniform accounting practices for income recognition and provisioning against bad and doubtful debts" came into existence. In line with Basel I regulations, following the advice of the Narasimham Committee I, it was decided that Indian banks needed to meet the 8 per cent or capital to risk-weighted assets ratio (CRAR) mark by 1996 (Ghosh et al, 2003). The Narasimham Committee I also recommended issuance of new licenses to privately owned banks. Among other banking sector reforms, there were, interest rate deregulation making a provision for public sector banks to raise up to 49 per cent of their equity in the capital market besides the gradual reduction of the Statutory Liquidity Ratio (SLR) and the Cash Reserve Ratio (CRR) as a measure to perk up the banks' profitability. These got followed up by Narasimham Committee II recommendations with regards to classification of assets, raising the CRAR mark from 8 to 10 per cent and setting up of Asset Reconstruction Companies (ARCs) that would take due care of the stressed assets of Indian banks (Chakraborty, 2010). Since then RBI's prudential regulation policies have taken care of asset classification and the structuring of bank's advances portfolio.

The banking sector has grown manifold in size as compared to the days of bank nationalization. In this phase, from 1969 to 2015 , the number of commercial banks went up from 89 to 152 - a quantum jump of sorts; consequently increasing economy's dependence on bank finance.

Table 1: Trends in bank's non-performing loans to total gross loans (per cent) : India vs. BRICS

\begin{tabular}{llllllll}
\hline Country Name & $\mathbf{2 0 1 0}$ & $\mathbf{2 0 1 1}$ & $\mathbf{2 0 1 2}$ & $\mathbf{2 0 1 3}$ & $\mathbf{2 0 1 4}$ & $\mathbf{2 0 1 5}$ & $\mathbf{2 0 1 6}$ \\
\hline Brazil & 3.11 & 3.47 & 3.45 & 2.86 & 2.85 & 3.31 & 3.92 \\
\hline Russian Federation & 8.23 & 6.59 & 6.03 & 6.00 & 6.73 & 8.35 & 9.44 \\
\hline India & 2.39 & 2.67 & 3.37 & 4.03 & 4.35 & 5.88 & 9.19 \\
\hline China & 1.13 & 0.96 & 0.95 & 1.00 & 1.25 & 1.67 & 1.75 \\
\hline South Asia & 14.75 & 4.70 & 4.96 & 5.58 & 7.78 & 8.40 & 9.62 \\
\hline World & $\mathbf{3 . 8 9}$ & $\mathbf{3 . 7 1}$ & $\mathbf{3 . 6 9}$ & $\mathbf{4 . 0 3}$ & $\mathbf{4 . 0 7}$ & $\mathbf{4 . 0 9}$ & $\mathbf{3 . 9 2}$
\end{tabular}

Source: Compiled from World Bank database

In the recent years, the stressed assets problem has come to the forefront with bank credit and deposit levels on the fall, especially since 2013. It is interesting to note that since 2000, the share of private sector banks has gone up over time but the actual number of private sector banks has decreased. It is an indication of the fact that RBI has been very careful in giving out banking licenses to private sector entities. Even today, in this era of globalization, public sector banks in India still accounts for a major share where Government ownership is 51 per cent or even higher. The point is, if there is a banking crisis of some kind it will eventually manifest itself into a fiscal problem given that the government bears bulk of the burden in the recapitalization process of the PSU banks in India. The present government at the center inherited most of the NPAs from its predecessor but even the present government's woes 
continue and the telecom sector being the worst hit with its share of NPAs in total NPAs of infrastructure sector standing at 8.7 per cent in 2016-17 as compared to 5 per cent in 2015-16 - one of the reasons for the peak in NPAs of public sector banks as given in Figure 1. In the new millennium, from Rs.564.73 billion, i.e. 11.1 per cent of the gross advances; gross NPAs came down to Rs.389.68 billion at the end of March 2007. This was short lived as the onset of the US Subprime crisis worsened the situation and NPAs rose significantly between 2009 and 2012, a quantum jump from Rs.449.57 billion in 2009 to Rs.1124.89 billion in 2012 and further to Rs.1644.62 billion in 2013. The manifold increase in the level of NPAs of banks, especially public sector banks, almost quadrapled from Rs.599.26 billion in March 2010 to Rs.2272.64 billion in March 2014. The NPAs situation worsened from 2014 onwards before assuming gigantic proportions. India's position from 2010 onwards has gone from bad to worse when compared with the likes of Brazil, China and South Asian countries on the whole (see Table 1).

Table 2: The Recovery and write-off positions of Public Sector Banks (PSBs) in India in 2017 — the Top 10

\begin{tabular}{llll}
\hline Banks & $\begin{array}{l}\text { Bad-loans written off by PSBs } \\
(\mathbf{2 0 1 4 - 1 7 )} \text { in Rs. Crores }\end{array}$ & $\begin{array}{l}\text { Recovery from written off } \\
\text { amounts by PSBs (2014-17) } \\
\text { in Rs. Crores }\end{array}$ & Recovery Rate (\%) \\
\hline UCO Bank & 6087 & 0 & 0.0 \\
\hline Indian Overseas Bank & 10470 & 10 & 2.7 \\
\hline Allahabad Bank & 9533 & 257 & 2.9 \\
\hline IDBI Bank Ltd. & 16568 & 479 & 5.2 \\
\hline Corporation Bank & 10790 & 562 & 6.2 \\
\hline Bank of India & 17680 & 1099 & 8.7 \\
\hline Bank of Baroda & 10571 & 915 & 10.1 \\
\hline State Bank of India & 102587 & 10396 & 22.5 \\
\hline Punjab National Bank & 27814 & 6270 & 23.3 \\
\hline Canara Bank & 13917 & 3248 & 28.6 \\
\hline Syndicate Bank & 5363 & 1535 & 0.1 \\
\hline
\end{tabular}

Source: Reserve Bank of India (2017)

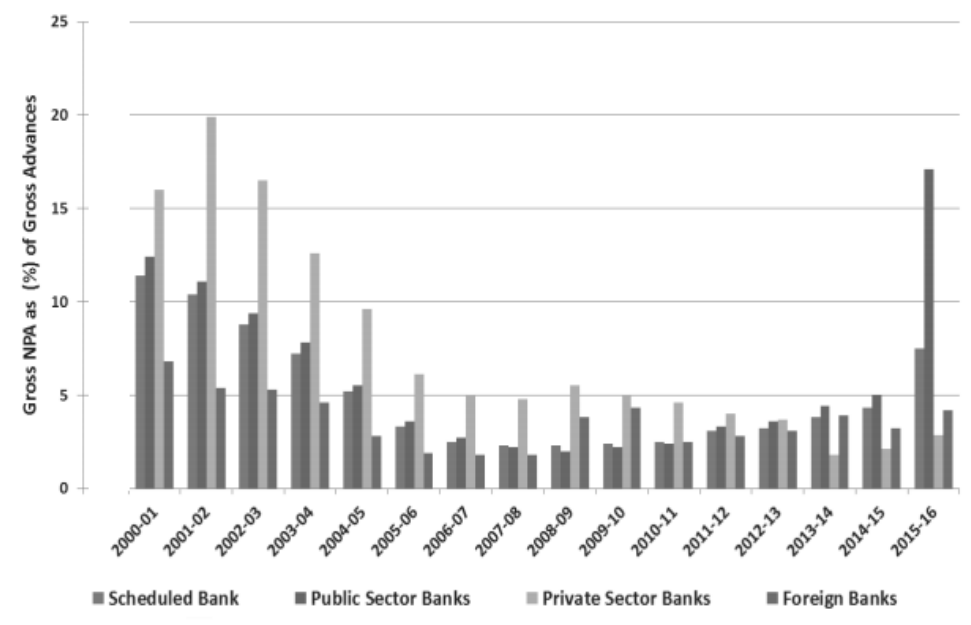

Figure 1: Movement in non-performing assets of banks in India from 2000 onwards; Source: Compiled from Handbook of Statistics on Indian Economy (2017)

Going by recent facts reported by Reserve Bank of India, 90 per cent of bad loans could not be recovered in the period between $2014-$ 17. Among the commercial banks, the worst performer is UCO Bank, which failed to recover a single rupee out of its Rs $6,087 \mathrm{crore}$ loan amount in the last four financial years followed by Indian Overseas and Allahabad Bank. Table 2 lists the banks which have failed to recover loans in the past four years and where they stand. The RBI Report (2017) shows that in the last four fiscal years 2014-15, 2015-16, 2016-17 and 2017-18 till December 31 — in aggregate, public sector banks (PSBs) could only recover Rs 29,343 
crore out of Rs 2.72 lakh crore of bad loans - a below par recovery rate of 10.77 per cent combined. This happened in spite of the central government infusing the lion's share of capital of Rs 52,311 crore to 11 weak banks to maintain their minimum regulatory capital requirement, earlier in January 2017. At the same time the Centre had given Rs 35,828 crore to nine strong banks were given. However, Syndicate Bank has fared relatively well among these worst performers (see Table 2).

Summing up the situation, taking a cross-country perspective highlight that among the countries worst affected with higher NPA ratios (to the total loans) Greece steals the show with a massive 36.37 per cent followed by Italy, Portugal, Ireland and India. However, unlike these countries, India has recently joined them and subsequently growing ever since 2013-14. With RBI (2017), predicitng a further rise in NPAs in 2018, i.e. 10.8 per cent as compared to the 10.2 per cent mark in September 2017, its time for the government to pay heed to this alarming situation. The question is - in this backdrop, will the Government of India's (GoI) strategy of bringing in the FRDI Bill provide any solution or will it boomerang and worsen the situation even further?

World vs.

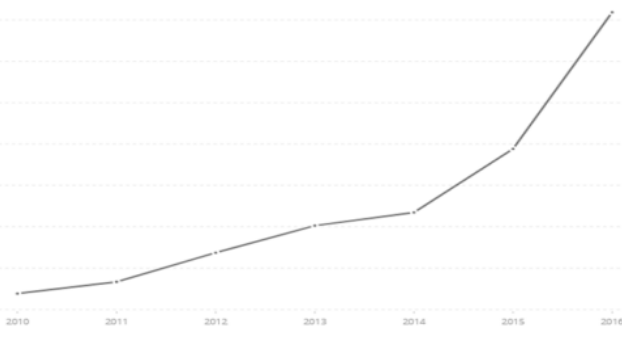

Figure 2: Bank non-performing loans to total gross loans (per cent) — India vs. World

\section{Research and Methodology}

\section{The structuralist-Macro model}

We develop a simple theoretical model to examine the implications of the banking sector reforms in the Indian context. The structure of the model is as follows, we have a small open economy divided into two sectors, viz., a real sector and a financial money sector. In the real sector, following the expenditure method of national income accounting and the standard assumptions of output being demand determined, we have,

$$
\begin{gathered}
Y=C[(1-t)(1-\bar{t}) Y]+I\left(\bar{r}, D, e P^{*}\right)+G+N X\left(Y, Y^{*}, e P^{*}, P\right) \\
Y=E\left(Y, Y^{*}, P^{*}, e, \bar{r}, D, G, t, \bar{t}\right)
\end{gathered}
$$

In equation $1, Y \equiv \mathrm{NDP}$ at factor cost as per national income terminology, $C$ is consumption which is a function of disposable income, $I \equiv$ investment, $r \equiv$ interest rate, $D \equiv$ Central bank's credit to the commercial banks and $t \equiv \operatorname{direct}$ tax rate and $\bar{t}$ is the indirect tax rate. Investment is a function of rate of interest the exchange rate while $P^{*} \equiv$ foreign price in foreign currency, $e \equiv$ nominal effective exchange rate and $P \equiv_{\text {domestic price level, }} N X \equiv_{\text {net exports and }} Y^{*} \equiv$ GDP of whole of the other countries of the world except the domestic economy.

Given the small country assumption holds good, $P^{*}$ and $Y^{*}$ is assumed to be given. In the Indian context, given that CRR, SLR, REPO and other policy rates are regulated by the central bank exogenously, the assumption of interest rates being fixed at a particular

level follows. But additionally, we assume that the interest charged by banks on loans is a function of the CRR, i.e., ${ }^{r}=f(\mu)$. Also, the central government to finance its expenditure borrows from the central bank and from the central banks's balance sheet it follows that, 


$$
G=\frac{d H}{P}=\frac{d D}{P}
$$

Moving on to the extenal sector equilibrium, the net capital inflow function has been heavily drawn from Mukherjee and Karmakar (2018) and given as,

$$
K=K\left(\bar{r}-r^{*}, Y, Y^{*}, e\right)
$$

where, $\left(\bar{r}-r^{*}\right)$ represents the interest rate differential and $r^{*}$ represent the foreign rate of interest and $\bar{r}$ is the interest rate in the domestic economy. Following a flexible exchange rate structure, BOP equilibrium is given as,

$$
\begin{gathered}
K=K\left(\bar{r}-r^{*}, Y, Y^{*}, e\right)+N X\left(Y, Y^{*}, P^{*}, P, e\right)=0 \\
\Rightarrow B\left(\bar{r}-r^{*}, Y, Y^{*}, e, P^{*}\right)=0
\end{gathered}
$$

The model can be generalized by incorporating other financial institutions but in our case, for simplicity, following Ghosh et al. (2018), we assume that there are only banks. Moreover, these banks are involved in accepting deposits and selling equities to raise their funds. Whatever fund is generated happens in the primary market. The secondary market remains subservient in this regard as secondary market in equities does not play a part in the creation of additional fund. Banks cannot sell as many securities as they want they because a demand constraint operates on the consumer side. Now, the consumers hold fraction of their money in the form of equity $\left(k_{1}\right)$, in the form of deposits $\left(k_{2}\right)$ and in the form of currency $\left(k_{3}\right)$. Banks sell equities to meet the capital adequacy requirement and finance a part through their exisiting reserves. The amount of equities that bank can sell is,

$E Q_{S}=\frac{1}{\lambda}(1-\mu) d D$ where, $\lambda$ is the capital adequacy ratio, ${ }^{\mu}$ is the CRR and $E Q_{S}$ is the supply of equity by the banks and hence also determines the amount of loans banks can give.

On the demand side for new equities, we have,

$$
E Q_{d}=k_{1}(Y-C(Y))
$$

Note that in the consumption function we suppress the direct and indirect tax rates for simplicity and without loss of any generality. Therefore, the level of new deposits that commercial banks can create will be,

$$
d D=k_{2}[Y-C(Y)]
$$

In India, under Reserve Bank of India's Master Circular (2014) on exposure in capital markets, for banks there is a umbrella limit and with such restrictions on the amount banks can raise, the supply of loans become,

$$
E Q_{S}=\lambda k_{1}[Y-C(Y)]
$$

Suppose, the bank knows about quality borrowers and about their credit worthiness for sure so when the investment function is considered, the focus will only be on those borrowers who are rationed in the credit market. Following Bernanke et al. (1996), expectations of borrowers in the investment function, we introduce the investment function as,

$$
I=I^{Q}\left(\begin{array}{l}
o \\
r
\end{array}, \varepsilon_{Q}\right)+\beta(N P A)\left[\left(\lambda k_{1}[Y-C(Y)]\right)-I^{Q}\left(\begin{array}{l}
o \\
r
\end{array}, \varepsilon_{Q}\right)\right]
$$

Here, the first component in equation (5) is actually investment on account of creditworthy borrowers and the second component is for the non-creditworthy ones. $\beta$ denotes the fraction of banks' remaining equity after giving to creditworthy borrowers that are disbursed out to the non-creditworthy ones. These non-creditworthy borrowers are rationed and hence the justification of the $\beta$ fraction; this fraction is also conditioned on the stock of non-performing assets of banks. ${ }^{\varepsilon_{Q}}$ is the expectation of creditworthy borrowers.

Now, its time to modify the aggrgate demand function in equation (1) after incorporating the required changes as discussed in equation (5), we have in equation (6),

$$
Y=C[(1-t)(1-\bar{t}) Y]+\left\{I^{Q}\left(\begin{array}{l}
o \\
r, \varepsilon_{Q}
\end{array}\right)+\beta(N P A)\left[\left(\lambda k_{1}(Y-C[(1-t)(1-\bar{t}) Y])\right)-I^{Q}\left(\begin{array}{l}
o \\
r, \varepsilon_{Q}
\end{array}\right)\right]\right\}+G+N X\left(Y, Y^{*}, e P^{*}, P\right)
$$


Before going into the propositions, two more simplifying assumptions - i) following Taylor's approximation, this model linearizes the consumption function and ii) Non-performing assets of banks (NPA as denoted here) is also assumed to be a function of the expectation $\left(E_{Q}\right)$ investors have regrading supervision, monitoring, regulation of non-performing assets

\section{Proposition}

On account of stricter regulations and pressure of regulations imposed on banks in this era of globalization, the effect through an exogenous fall in the aggregate demand brings about a deep recession.

Totally differentiating equation (6) and after several manipulations, one can derive,

$$
d Y=\frac{d G}{1-\left[\beta(N P A) \lambda k_{1}+\{c(1-t)(1-\bar{t})\}\left[1-\beta(N P A) \lambda k_{1}\right]\right]}+\frac{(1-\beta) I^{Q} d \varepsilon_{Q}}{1-\left[\beta(N P A) \lambda k_{1}+\{c(1-t)(1-\bar{t})\}\left[1-\beta(N P A) \lambda k_{1}\right]\right]}
$$

The best way of tackling recessions and the associated problem of non-performing assets is to undertake appropriate expansionary fiscal policy, i.e. increase $\mathrm{G}$ (the aggregate demand function in equation 6 will shift up which will increase the level of $Y$ [see the first component in equation 7); this in turn will finance the autonomous decline in investment witnessed from the second component in equation 7 and then depending on the strength of these two effects the fate of the economy will be determined] to put the economy on an upswing, provide debt relief to the ailing firms until the economy revives and provide adequate capital to banks to fully compensate for their losses until the economy begins to boom again and the firms begin to make profit and start paying back loans along with interest. So the first effect of expansionary fiscal policy needs to dominate if the problem of recession has to be resolved. In the context of USA, some of these policies were adopted to bring the economy out of the meltdown in 2008 (Mishkin, 2011). This goes for the policy makers - if instead of adopting intelligent anti-recessionary policies, the government takes the commercial banks to task, it will have the confidence of the banks', savers and investors' badly shaken, credit crunches will begin and the economy will slip into recession. The essence of this proposition in the Indian context is that if the much glorified 'FRDI Bill' is passed then the investors' confidence will take a beating and go in for a toss. The moment the expectations of investors, $E_{Q}$ is shaken, they will be reluctant to hold their money in the form of savings, the banking sector of the economy will not only collapse but along with it also plot the collapse of the entire economy.

\section{Data Availability}

The data used in this study from 2005-2017 on the movement of non-performing assets (NPAs) of 42 public and private commercial banks (excluding foreign banks operating in the country) has been extracted from the Statistical Tables Relating to Banks in India under Reserve Bank of India's Handbook of Statistics on the Indian Economy database. The broad categories of banks considered here are - i) State Bank of India \& its Associates, ii) Nationalized banks and iii) Private Sector Commercial banks. The data for the variables used, namely, GDP growth rate $(g)$, Inflation rate $(i)$, NEER $(n)$, combined deposit growth rate $(d)$, government expenditure (revenue and capital expenditure combined) $(g e)$ and the non-performing assets of banks as a percentage of total GDP (NPAs) in this task have been compiled from Handbook of Statistics on the Indian Economy i.e. Reserve Bank of India (RBI) database, the Planning Commission Yearbook and Open Government Data (OGD platform database) after shifting the base year for $g$ to 2011-12 and reconstructing the entire series based on 2011-12 as the base year. Also, annual data on the required components of revenue and capital expenditure of GoI across the different ministries have been collected from budget details of several years (available at http://indiabudget.nic.in/).

It should be noted that before we move onto to the estimation of the model, checking stationarity of the variables becomes necessary. To check for the stationarity of the variables, we go for Unit Root Test for every individual series applying the Dickey and Fuller $(1979,1981)$ test statistic and Akaike Information Criterion (AIC), with trend and intercept for knowing whether the series is trend stationary (TS) or difference stationary (DS). After conducting this unit test we see that all our variables attain stationarity at their level values (see results in Table 3). This is very much expected given the time period considered in this study. Therefore, there is no chance of getting a long-run cointegrated relationship. To be sure about the model strucutre, this paper also checks for the causality issue (see Table 4).

We use the following model to test for the presence of unit roots,

$$
\Delta y_{t}=\mu+\rho t+\tau y_{t-1}+\sum_{j=1}^{k} \varphi_{j} \Delta y_{t-j}+e_{t}
$$

where, ${ }^{\mu}$ denotes the constant, $\rho$ is the coefficient on time trend and $j$ is the order of lag of the autoregressive (AR) process and $\Delta y_{t-j}$ captures autoregressive moving average (ARMA) effects (Dickey \& Fuller, 1979, 1981).

The test process is performed under the null hypothesis of $\tau=0$ tested against the alternative hypothesis of $\tau<0$. If the null hypothesis is rejected, it can be concluded that there is no unit root and the data is stationary. 
Table 4: Unit Root results

\begin{tabular}{lllll}
\hline Variables & Level of Stationarity & Test statistic & Probability value & Order of Integration \\
\hline $\boldsymbol{g}$ & Level & -6.98 & $0.00^{*}$ & $\mathrm{I}(0)$ \\
\hline $\boldsymbol{i}$ & Level & -5.40 & $0.00^{*}$ & $\mathrm{I}(0)$ \\
\hline $\boldsymbol{n}$ & Level & -6.33 & $0.00^{*}$ & $\mathrm{I}(0)$ \\
\hline $\boldsymbol{d}$ & Level & -5.21 & $0.00^{*}$ & $\mathrm{I}(0)$ \\
\hline $\boldsymbol{g} \boldsymbol{N}$ & Level & -4.99 & $0.00^{*}$ & $\mathrm{I}(0)$ \\
\hline $\boldsymbol{N P A s}$ & Level & -5.44 & $0.00^{*}$ & $\mathrm{I}(0)$ \\
\hline
\end{tabular}

Source: * implies significance at 95 per cent level; Results as obtained in Eviews 7

Granger causality is used to test whether the lagged values of one variable enter into the equation of another variable (see Table 5 for the results).

The null hypothesis $\left(\mathrm{H}_{0}\right)$ under Granger Causality (Granger, 1969) is -

$\mathrm{H}_{0}=$ no granger causality and $\mathrm{H}_{1}$ (alternative hypothesis) = there exists granger causality.

Table 5: Pairwise Granger Causality results

\begin{tabular}{|c|c|c|}
\hline Null Hypothesis & W-bar statistic & Probability \\
\hline$g$ does not Granger Cause $i$ & 0.93 & 0.99 \\
\hline$i$ does not Granger Cause $g$ & 1.76 & $0.01 *$ \\
\hline Null Hypothesis & W-bar statistic & Probability \\
\hline$g$ does not Granger Cause $n$ & 1.01 & 0.60 \\
\hline$n$ does not Granger Cause $g$ & 1.97 & $0.00 *$ \\
\hline Null Hypothesis & W-bar statistic & Probability \\
\hline$g$ does not Granger Cause $d$ & 0.98 & 0.99 \\
\hline$d$ does not Granger Cause $g$ & 1.99 & $0.00^{*}$ \\
\hline Null Hypothesis & W-bar statistic & Probability \\
\hline$g$ does not Granger Cause $g e$ & 1.02 & 0.60 \\
\hline$g e$ does not Granger Cause $g$ & 2.88 & $0.00 *$ \\
\hline Null Hypothesis & W-bar statistic & Probability \\
\hline$g$ does not Granger Cause $N P A s$ & 0.67 & 0.92 \\
\hline NPAs does not Granger Cause $g$ & 3.77 & $0.00 *$ \\
\hline Null Hypothesis & W-bar statistic & Probability \\
\hline$n$ does not Granger Cause $i$ & 0.72 & 0.99 \\
\hline$i$ does not Granger Cause $n$ & 1.01 & 0.60 \\
\hline Null Hypothesis & W-bar statistic & Probability \\
\hline$n$ does not Granger Cause ge & 1.11 & 0.50 \\
\hline ge does not Granger Cause $n$ & 0.59 & 1.00 \\
\hline Null Hypothesis & W-bar statistic & Probability \\
\hline$n$ does not Granger Cause $d$ & 0.44 & 1.00 \\
\hline$d$ GDP does not Granger Cause $n$ & 0.58 & 1.00 \\
\hline Null Hypothesis & W-bar statistic & Probability \\
\hline$n$ does not Granger Cause NPAs & 0.55 & 1.00 \\
\hline NPAs GDP does not Granger Cause $n$ & 0.87 & 0.92 \\
\hline Null Hypothesis & W-bar statistic & Probability \\
\hline$d$ does not Granger Cause $g e$ & 0.51 & 1.00 \\
\hline$g e$ GDP does not Granger Cause $d$ & 0.91 & 0.99 \\
\hline Null Hypothesis & W-bar statistic & Probability \\
\hline$d$ does not Granger Cause $N P A s$ & 0.93 & 0.99 \\
\hline
\end{tabular}




\begin{tabular}{lll}
\hline Table Cont'd & & \\
NPAs GDP does not Granger Cause $d$ & 0.80 & 0.99 \\
\hline Null Hypothesis & W-bar statistic & Probability \\
\hline ge does not Granger Cause NPAs & 0.99 & 0.99 \\
\hline NPAs GDP does not Granger Cause $g e$ & 0.59 & 1.00 \\
\hline Null Hypothesis & W-bar statistic & Probability \\
\hline$i$ does not Granger Cause $d$ & 0.53 & 1.00 \\
\hline$d$ GDP does not Granger Cause $i$ & 0.81 & 0.99 \\
\hline Null Hypothesis & W-bar statistic & Probability \\
\hline$i$ does not Granger Cause $g e$ & 1.09 & 0.51 \\
\hline$g e$ GDP does not Granger Cause $i$ & 0.59 & 1.00 \\
\hline Null Hypothesis & W-bar statistic & Probability \\
\hline$i$ does not Granger Cause $N P A s$ & 0.32 & 1.00 \\
\hline$N P A s$ GDP does not Granger Cause $i$ & 0.80 & 0.99 \\
\hline
\end{tabular}

Source: * implies significance at 95 per cent level; Results as obtained in Eviews7

The results of the pairwise Granger Causality test as reported in Table 5 points out that all the explanatory variables used in the study - Inflation rate $(i)$, NEER $(n)$, combined deposit growth rate $(d)$, government expenditure, including both revenue and capital expenditure combined) ( $g e$ ) and the non-performing assets of banks as a percentage of total GDP (NPAs) uni-directionally influence growth. The causality runs from these explanatory variables, as mentioned, to growth. Thus, Granger non-causality is synonymous with weak exogeneity (Brida et al., 2009) and the model used here is not only consistent with the factors on which economic growth depends as considered in the theoretical model in equation (7) but also with the causality results in Table 5,

$$
g=A+\delta(i)+\alpha(n)+\beta(d)+\gamma(g e)+\theta(N P A s)+\varepsilon
$$

\section{Estimation Results}

Coming to the estimation procedure, this paper makes use of Generalized Method of Moments (GMM) approach which satisfies the properties of efficiency even in case of heteroskedasticity. We use GMM as a class of estimators particularly to address the potential endogeneity issues among the explanatory variables. Given the construction of the model, there can possibly be an endogeneity issue so this technique of building up instruments from lagged values (in our case it is two period lagged values) which solves the problem. Also, GMM is much more convenient for estimating a model without entirely knowing the nature of the underlying probability distribution for the data (see also Siddiquia \& Ahmed, 2013). Consider a generic model,

$y=X \beta+\varepsilon$ and $Z$ is a matrix of IV's. The moment conditions are given by :

$$
E\left(Z^{\prime} \varepsilon\right)=0-i . e ., E\left(Z^{\prime}(y-X \beta)\right)=0
$$

So, the minimization problem becomes,

$\min _{\beta}\left[\frac{1}{n}\left(Z^{\prime}(y-X \beta)\right)^{\prime} W_{n} \frac{1}{n}\left(Z^{\prime}(y-X \beta)\right)\right]_{\text {having }}$

$W_{n}=\left[\frac{1}{n^{2}} Z^{\prime} \Omega Z\right]^{-1}$ as the heteroskedasticity consistent weight matrix and,

$\Omega$ is the asymptotic covariance matrix of the error terms of order $n \times n$.

We, thus, have,

$$
\hat{\beta}_{G M M}=\left[X^{\prime} Z\left(Z^{\prime} \Omega Z\right)^{-1} Z^{\prime} X\right]^{-1}\left[X^{\prime} Z\left(Z^{\prime} \Omega Z\right)^{-1} Z^{\prime} y\right]
$$

where,

$Z: n \times L ; X: n \times K$ i.e. having $\mathrm{K}$ such explanatory variables with $\mathrm{L}$ instruments each. 
Table 6: GMM results

\begin{tabular}{llll}
\hline Variables & Coefficient & z value & $\boldsymbol{P}>|z|$ \\
\hline $\boldsymbol{i}$ & -0.616 & 14.12 & $0.00^{*}$ \\
\hline $\boldsymbol{n}$ & 0.491 & -6.212 & $0.00^{*}$ \\
\hline $\boldsymbol{d}$ & 0.990 & -7.375 & $0.00^{*}$ \\
\hline $\boldsymbol{g} \boldsymbol{N P A s}$ & 0.812 & -2.351 & $0.00^{*}$ \\
\hline
\end{tabular}

Source: * implies significance at 95 per cent level; Results as obtained in Eviews7

\section{The structuralist-Macro model}

From the results derived in Table 6, high significance and the negative sign of the inflation rate parameter shows that there are huge growth costs associated with inflation in terms of income redistribution, tax structure, losing out on international competitiveness, etc.,-a piece of evidence supporting the findings by Pattanaik and Nadhanael (2013). Now, NEER having a positive and a significant relationship with GDP growth rate implies that with increase in the growth rate of exchange rate (i.e. depreciation of the home currency value vis-à-vis some foreign currency) the economic growth will be boosted and hence the rise through the exports channel. Apart from inflation, all the other parameters affect GDP growth positively and significantly. Interestingly, contrary to the existing literature, in the period under consideration, there exists a significant and positive impact of NPAs on GDP growth rate of India. This is indeed a worrisome factor and the interpretation of such a paradoxical result becomes crucial. As per the results in the model (see Table 6), i.e. with 1 percentage unit rise in NPAs there is a 0.05 per cent rise in GDP growth. In the light of the above, it can be argued that within the period in question, the improvement in the real economy was not sufficient to bring about a momentous reduction in the NPAs of banks. Although significant, there is a very weak relationship between NPAs of banks and growth for the period under consideration.

What is more, this paradoxiacal result supports the diagrammatic relation in Figure 4. In this context, one can argue that NPAs resulting from expansion of credit does not necessarily result in a fall in the GDP growth rate. Given that, this paper considers all the banks together, so on the average at the macro level, losses arising out of NPAs from some banks have been negated with more qualitative loans arising out of some of the best performing banks. In other words, the banking sector as a whole (including the worst performing banks in terms of NPAs) has actually minimized the impact of NPAs on growth may be through buyouts of portfolio, proper collaterization of loans, through proper credit swaps etc. Research studies incorporate micro foundations of NPAs in their models and present how grave the situation is in India but one needs to also look at the NPA problem at the aggregate i.e. from a macroeconomic perspective. Things completely change when the macro dimensions come into the picture. Now, if FRDI Bill is introduced what the situation will become that it is not known. It is wisely to note that it is not only NPAs but also a series of global macroeconomic and financial parameters, weak external demand, soaring prices, increasing twin deficits combined with weak investments that brought down the growth rates in the beginning of this decade (Mukherjee \& Karmakar, 2018). The paper reminds the policymakers that at the aggregate level it is not always NPAs that have an impact on growth but a host of other factors are responsible. Therefore, policy strategists should be ready to implement intelligent policies to solve such puzzles as and when they crop up.

\section{Conclusion}

Given the theoretical model, a researcher can always extend this empirical model in different dimensions and perspectives. Having data for a wide range of countries across the world over a period of time will allow the model to be estimated in a panel-data setup. Comparing the results derived herein with the panel-data setup results can be a novel initiative. Moreover, comparing the movement of NPAs of banks in the pre-liberalization and the post-liberalization period after introducing structural breaks at appropriate points of time can be worth exploring and has been left for further research. Also, replicating the dynamics of the model for other countries in Asia and then comparing the results with the Indian case are some of the exercises that can be carried out as a part of the future research possibilities this paper paves the way for.

In an idealized situation, commercially organized banks, as so far evidenced, are subject to the vagaries of the market forces and as argued in the present paper, government's effort at arresting the growth of their non-performing assets can have wide ranging implications, i.e. using stricter regulations following an onset of recession may deepen the recession significantly. The author feels that the best way of tackling this problem is to adopt appropriate stabilization programmes to counter the recession as already argued in the theoretical modeling section. Also, it is opined here that banks should be a social institution aiming at maximization of welfare of the common masses and not become a commercial organization, per se, mainly driven by the profit motive. Private profit driven banks pull off the kind of disasters that the world witnessed in Japan 1991, US Subprime crisis in 2008-09 and the Eurozone debt crisis in 2010. Only time will tell to what extent the magnitude of impact of NPAs on GDP growth rises or falls in India. To bring it to a close, in India, the government is very anxious to recapitalize the banks but nothing much has materialized till date. The question the public is asking, are my banks safe given such regulations under the aegis of the FRDI Bill? The author believes that given such 
structural flaws in the bill, there will be severe economic consequences as already discussed. Hence, it is only a matter of time before this FRDI Bill either gets taken out or gets amended.

Author Contributions: Conceptualization, S.; methodology, S.; Data Collection, S.; formal analysis, S.; writing—original draft preparation, S.; writing - review and editing, S. All authors have read and agreed to the published the final version of the manuscript. Institutional Review Board Statement: Ethical review and approval were waived for this study, due to that the research does not deal with vulnerable groups or sensitive issues.

Data Availability Statement: The data presented in this study are available on request from the corresponding author. The data are not publicly available due to privacy.

Acknowledgement

The author reports no conflicts of interest. The author alone is responsible for the content and writing of the paper.

\section{Appendix A:}

\section{Key Terms}

Cointegration : Cointegration is an econometric characteristic where a collection of time series variables $\left(X_{1}, X_{2}, X_{3}, \ldots . X_{k}\right)$ being integrated of the same order (greater than zero i.e. non- stationary) can be combined to generate a linear combination from this collection of variables which is integrated of order zero (i.e. a stationary trend). Then the time series variables $X_{1}, X_{2}, X_{3}, \ldots . . X_{k}$ are said to be cointegrated.

FRDI Bill: The Union Cabinet, under the chairmanship of Prime Minister Shri Narendra Modi had approved the proposal to introduce a Financial Resolution and Deposit Insurance (FRDI) Bill in June 2017. The bill was tabled in the Lok Sabha in the Monsoon Session and submitted its report in December 2017. It paves way for an all-inclusive resolution framework for specified financial sector entities regarding how to deal with the bankruptcy situation of banks, insurance companies and financial sector entities in India, as per the statement given by the government. This FRDI Bill pushes for a resolution corporation to monitor the financial companies, to check their risk profiles and intervene in a critical situation when such financial institutions are on the verge of bankruptcy. If it is meant to secure the interest of the customers (or depositors), then why are we terrified? Recently, in this context, there has been a lot of furore among public in India. This brings us to the flaws in such an innovative policy meant for strategic management of NPAs of banks. Actually, anxiety creeps in through the inbuilt "bail-in clause" which says that to rescue a sick financial corporation (say, a bank, for instance) which is on the brink of becoming bankrupt, the creditors and depositors' money will be used to bail out that particular financial institution.

See for details the brief of the FRDI Bill 2017 at http://pib.nic.in/PressReleaseIframePage.aspx?PRID= 1514988

Granger causality: Granger Causality is a statistical hypothesis that asserts that a time series variable say X, is said to "Granger cause" another time series variable $\mathrm{Y}$, if and only if the past values of $\mathrm{X}$ contain adequate information to predict $\mathrm{Y}$.

Non-Performing Assets (NPA) ratio: Net NPAs are calculated by deducting provisions from gross NPAs. The net NPA to advances (loans) ratio is used as a measure of the overall quality of

the bank's loan book. The ratio is given by,

$$
\text { NPA ratio }=\frac{\text { Net non }- \text { performing assets }}{\text { Advances }}
$$

Recession: A recession is a phase in the business cycle which results in a general slowdown in economic activity. The triggering factors can be - a financial crisis, an external trade shock, an adverse supply shock or the bursting of an economic bubble. At times of recession, the indicators reflecting the overall macroeconomic performance, given by GDP, corporate profits, investment expenditure and inflation rate generally fall, while the unemployment rates rise.

Structuralist-macro model: Structuralist economics is a modeling approach to economics that emphasizes the importance of taking into account structural features in a developing country (typically, characterizing the different sectors in an economy, say, goods market, money market, external world, to name a few) when undertaking economic analysis. These are completely ad hoc models tailor made to suit the needs of the policymakers and have a strong accent on policy without any micro-economic foundations as such. This approach originated with the works of the Economic Commission for Latin America (ECLA) and is the brainchild of its director, Raúl Prebisch and Brazilian economist Celso Furtado.

Strategic Management: The process involves the formulation and implementation of the major goals and objectives taken by the government at the macro level or by the concerned bank at the micro level, based on continuous planning, monitoring, scrutiny and evaluation of all that is required to solve the NPAs problem of banks.

Stationarity: The statistical properties like mean, variance, autocorrelation, etc. of such a time series are all constant over a period of time. Statistical forecasting methods generally use this stationarity property through mathematical transformations in the process of predicting how the future varies in comparison to the past. It, thus, aims to identify whether there is unit root in the time series process or not. 


\section{References}

Adrian, T., \& Shin, H. S. (2008). Financial intermediaries, financial stability, and monetary policy. Retrieved from https://core.ac.uk/download/pdf/39379881.pdf

Banerjee, K. (2012). Credit and growth cycles in India: An empirical assessment of the lead and lag behaviour.Retrieved from http://www.esocialsciences.org/Download/repecDownlo ad.aspx?fname=A20121616403_20.pdf\&fcategory=Articles\&AId=4699\&fref=repec

Bebchuk, L. A., Cohen, A., \& Spamann, H. (2010). The wages of failure: Executive compensation at Bear Stearns and Lehman 2000-2008. Yale Journal on Regulation, 27(2), 257-282.

Beck, T., \& Levine, R. (2004). Stock markets, banks, and growth: Panel evidence. Journal of Banking \& Finance, 28(3), 423-442.

Bernanke, B. S., Gertler, M., \& Gilchrist, S. (1996). The flight to quality and the financial accelerator. Review of Economics and Statistics, 78(1), 1-15.

Brida, J. G., Lionetti, S., \& Risso, W. A. (2009). Lung run economic growth and tourism: inferring from Uruguay. Retrieved from http://doc.rero.ch/record/11329/files/wp0901.pdf

Burzynska, K. (2009). Financial Development and Economic Growth: The Case of Chinese Banking Sector. Retrieved from https://www.uwcentre.ac.cn/haut/wp-content/uploads/2013/11/chinese-banking-case-study.pdf

Chakraborty, I. (2010). Financial development and economic growth in India: An analysis of the post-reform period. South Asia Economic Journal, 11(2), 287-308.

Chaudhary, S. (2012). Performance appraisal of Indian banking sector: A comparative study of selected private and foreign banks. International Journal of Research in Computer Application \& Management, 2(6), 171-175.

Cheema, C. S., \& Agarwal, M. (2002). Productivity in commercial banks: A DEA approach. The Business Review, 8(1), 15-17.

Das, A., \& Ghosh, S. (2007). Determinants of credit risk in Indian state-owned banks: An empirical investigation. Retrieved from https://mpra.ub.uni-muenchen.de/17301/1/mpra_paper_17301.pdf

Diamond, D. W., \& Rajan, R. G. (2009). The credit crisis: Conjectures about causes and remedies. American Economic Review, 99(2), 606-10.

Dickey, D. A., \& Fuller, W. A. (1981). Likelihood ratio statistics for autoregressive time series with a unit root. Econometrica: Journal of the Econometric Society, 49(4), 1057-1072.

Dickey, D. A., \& Fuller, W. A. (1979). Distribution of the estimators for autoregressive time series with a unit root. Journal of the American Statistical Association, 74(366a), 427-431.

Espinoza, R., \& Prasad, A. (2010). Nonperforming Loans in the GCC Banking System and their Macroeconomic Effects. Retrieved from https://www.researchgate.net/profile/A_Prasad/

publication/228201846_Nonperforming_Loans_in_the_GCC_Banking_System_and_Their_Macroeconomic_Effects/links/ 0c96052e2bd13f2e44000000/Nonperforming-Loans-in-the-GCC-Banking-System-and-TheirMacroeconomic-Effects.pdf

Ghosh, A., Ghosh, C., \& Bhattacharjee, M. (2018). Macroeconomics of Development and Banking Sector Reforms in India. Artha Beekshan, 27(1), 60-77.

Ghosh, S., Nachane, D. M., Narain, A., \& Sahoo, S. (2003). Capital requirements and bank behaviour : An empirical analysis of Indian public sector banks. Journal of International Development: The Journal of the Development Studies Association, 15(2), 145-156.

Gorton, G. B. (2010). Slapped by the invisible hand: The panic of 2007. New York, USA: Oxford University Press.

Gupta, B. (2012). A comparative study of non-performing assets of SBI \& associates \& other public sector banks. SIT Journal of Management, 2(2), 175-189.

Granger, C. W. (1969). Investigating causal relations by econometric models and cross-spectral methods. Econometrica: Journal of the Econometric Society, 37(3), 424-438.

Ketkar, K. W., Noulas, A. G., \& Agarwal, M. M. (2003). An analysis of efficiency and productivity growth of the Indian banking sector. Finance India, 17(2), 511-521.

Kirkpatrick, G. (2009). The corporate governance lessons from the financial crisis. OECD Journal: Financial Market Trends, 2009(1), 61-87.

Makri, V., Tsagkanos, A., \& Bellas, A. (2014). Determinants of non-performing loans: The case of Eurozone. Panoeconomicus, 61(2), 193-206.

Messai, A. S., \& Jouini, F. (2013). Micro and macro determinants of non-performing loans. International Journal of Economics and Financial Issues, 3(4), 852-860.

Mishkin, F. S. (2011). Monetary Policy Strategy:Lessons from the Crisis. Retrieved from https://www.bancaditalia.it/pubblicazioni/altri-atti-seminari/2011/paper-Mishkin.pdf

Miwa, Y., \& Ramseyer, J. M. (2002). Banks and economic growth: implications from Japanese history. The Journal of Law and Economics, 45(1), 127-164.

Mukherjee, S., \& Karmakar, A. K. (2018). A Hardheaded Look: How Did India Feel the Tremors of Recent Financial Crises?. In Global Approaches in Financial Economics, Banking, and Finance (pp. 25-51). Springer, Cham.

Nagaraj, R. (2013). India's dream run, 2003-08. Economic and Political Weekly, 48(20), 39-51. 
Patidar, S., \& Kataria, A. (2012). An Analysis of NPA in Priority Sector Lending: A Comparative Study Between Public Sector Banks and Private Sector Banks of India. Bauddhik, 3(1), 54-69.

Pattanaik, S., \& Nadhanael, G. V. (2013). Why persistent high inflation impedes growth? An empirical assessment of threshold level of inflation for India. Macroeconomics and Finance in Emerging Market Economies, 6(2), 204-220.

Rajaraman, I., Bhaumik, S., \& Bhatia, N. (1999). NPA variations across Indian commercial banks: Some findings. Economic and Political Weekly, 34(3/4), 161-168.

Ranjan, R., \& Dhal, S. C. (2003). Non-Performing Loans and Terms of Credit of Public Sector Banks in India: An Empirical Assessment. Reserve Bank of India Occassional Papers, 24 (3).

Rajaraman, I., \& Vasishtha, G. (2002). Non-performing loans of PSU banks: Some panel results. Economic and Political weekly, $37(5), 429-435$.

Reddy, A. (2004). Banking sector liberalization and efficiency of Indian banks. The IUP Journal of Bank Management, 3(2), 3753.

Reserve Bank of India. (2017). Financial Institutions: Soundness and Resilience. Retrieved rom https://rbi.org.in/Scripts/PublicationReportDetails.aspx?UrlPage=\&ID=887

Reserve Bank of India. (2014). Master Circular-ExposureNorms. Retrieved from https://rbi. org.in/Scripts/BS_ViewMasCirculardetails.aspx?id=9875

Saggar, S. (2005). Commercial Banks in India. New Delhi, India: Deep \& Deep Publications Pvt Ltd.

Siddiqui, D. A., \& Ahmed, Q. M. (2013). The effect of institutions on economic growth: A global analysis based on GMM dynamic panel estimation. Structural Change and Economic Dynamics, 24, 18-33.

Stiglitz, J. E. (1993). The role of the state in financial markets. The World Bank Economic Review, 7(suppl_1), 19-52.

Publisher's Note: Bussecon International stays neutral with regard to jurisdictional claims in published maps and institutional affiliations.

\section{(c) (i)}

International Journal of Business Ecosystem and Strategy by Bussecon International Academy is licensed under a Creative Commons Attribution 4.0 International License. 